\title{
Parkinson's Disease-Linked LRRK2-G2019S Mutation Alters Synaptic Plasticity and Promotes Resilience to Chronic Social Stress in Young Adulthood
}

\author{
Bridget A. Matikainen-Ankney, ${ }^{\star}$ Nebojsa Kezunovic, ${ }^{\star} \mathbb{C}^{-C a r o l i n e ~ M e n a r d, ~}{ }^{\circledR}$ Meghan E. Flanigan, Yue Zhong, \\ (D) Scott J. Russo, ${ }^{-D e a n n a}$ L. Benson, and $\mathbb{C}$ George W. Huntley \\ Department of Neuroscience, Friedman Brain Institute, and the Graduate School of Biomedical Sciences, Icahn School of Medicine at Mount Sinai, \\ New York, New York 10029
}

The G2019S mutation in leucine-rich repeat kinase 2 (LRRK2) is a prevalent cause of late-onset Parkinson's disease, producing psychiatric and motor symptoms, including depression, that are indistinguishable from sporadic cases. Here we tested how this mutation impacts depression-related behaviors and associated synaptic responses and plasticity in mice expressing a Lrrk2-G2019S knock-in mutation. Young adult male G2019S knock-in and wild-type mice were subjected to chronic social defeat stress (CSDS), a validated depression model, and other tests of anhedonia, anxiety, and motor learning. We found that G2019S mice were highly resilient to CSDS, failing to exhibit social avoidance compared to wild-type mice, many of which exhibited prominent social avoidance and were thus susceptible to CSDS. In the absence of CSDS, no behavioral differences between genotypes were found. Whole-cell recordings of spiny projection neurons (SPNs) in the nucleus accumbens revealed that glutamatergic synapses in G2019S mice lacked functional calciumpermeable AMPARs, and following CSDS, failed to accumulate inwardly rectifying AMPAR responses characteristic of susceptible mice. Based on this abnormal AMPAR response profile, we asked whether long-term potentiation (LTP) of corticostriatal synaptic strength was affected. We found that both $D_{1}$ receptor $\left(D_{1} R\right)$ - and $D_{2} R$-SPNs in $G 2019 S$ mutants were unable to express LTP, with $D_{2} R$-SPNs abnormally expressing long-term depression following an LTP-induction protocol. Thus, G2019S promotes resilience to chronic social stress in young adulthood, likely reflecting synapses constrained in their ability to undergo experience-dependent plasticity. These unexpected findings may indicate early adaptive coping mechanisms imparted by the G2019S mutation.

Key words: chronic social defeat stress; LRRK2; LTP; nucleus accumbens; resilience; striatum

\section{Significance Statement}

The G2019S mutation in LRRK2 causes late-onset Parkinson's disease (PD). LRRK2 is highly expressed in striatal neurons throughout life, but it is unclear how mutant LRRK2 affects striatal neuron function and behaviors in young adulthood. We addressed this question using Lrrk2-G2019S knock-in mice. The data show that young adult G2019S mice were unusually resilient to a depression-like syndrome resulting from chronic social stress. Further, mutant striatal synapses were incapable of forms of synaptic plasticity normally accompanying depression-like behavior and important for supporting the full range of cognitive function. These data suggest that in humans, LRRK2 mutation may affect striatal circuit function in ways that alter normal responses to stress and could be relevant for treatment strategies for non-motor PD symptoms.

\section{Introduction}

Leucine-rich repeat kinase 2 (LRRK2) is a large, multifunctional protein comprising a kinase and GTPase catalytic core and other domains (Mata et al., 2006). Pathogenic mutations within the catalytic core contribute to late-onset familial Parkinson's disease (PD), with the LRRK2-G2019S missense mutation, which is lo- 
cated in the kinase domain and increases kinase activity 2- to 3 -fold, the most prevalent, accounting for $1-30 \%$ of all PD depending on the population (West et al., 2005; Jaleel et al., 2007; Healy et al., 2008; Paisán-Ruiz et al., 2013). Disease progression in LRRK2-G2019S carriers is clinically indistinguishable from idiopathic cases, suggesting common underlying mechanisms of pathogenesis. In particular, psychiatric symptoms, including depression and anxiety, are common non-motor symptoms in both LRRK2-G2019S and idiopathic PD patients (Ishihara and Brayne, 2006; Gaig et al., 2014), often first appearing earlier than the onset of motor symptoms (Hawkes et al., 2010; Gustafsson et al., 2015; Pont-Sunyer et al., 2015). The neurobiology underlying PD-associated non-motor symptoms is largely unknown.

LRRK2 expression is enriched in cortex, and dorsal and ventral striatum, including the nucleus accumbens (NAc), in mice and humans (Taymans et al., 2006; Higashi et al., 2007; Lee et al., 2010). Although LRRK2 is expressed throughout life, expression levels in mouse striatum rise rapidly during early postnatal life coincident with ingrowth and establishment of corticostriatal and other excitatory afferent circuitry (Tepper et al., 1998; Giesert et al., 2013). This suggests an early role for LRRK2 in developing striatal circuits (Parisiadou et al., 2014), which could become modified by the G2019S mutation. Indeed, we showed previously in mice carrying a homozygous knock-in Lrrk2G2019S mutation that corticostriatal afferent activity is significantly elevated and dendritic spines of striatal spiny projection neurons (SPNs) are abnormally enlarged at 3 postnatal weeks (Matikainen-Ankney et al., 2016). Part of these findings was confirmed recently with a different Lrrk2-G2019S knock-in line of mice (Volta et al., 2017). Behavioral consequences of such early synaptic changes are unknown. Although Lrrk2-G2019S knock-in mice do not exhibit PD-like, age-related degeneration of dopamine neurons, the impact of G2019S mutation on circuit function and behavior in humans before PD motor-symptom onset is not well understood. Thus, Lrrk2-G2019S knock-in mice are valuable tools for understanding mechanistically how mutant LRRK2 affects cells, circuits, and behaviors throughout life. In other studies, LRRK2-G2019S overexpression or knock-in mice show behavioral abnormalities, including anxiety and depressionlike behaviors, evident only by $10-12$ months of age, with a mild hyperkinesis evident at younger ages (Longo et al., 2014; Volta et al., 2015, 2017; Yue et al., 2015; Lim et al., 2018). This has led to the idea that despite early abnormalities in striatal circuitry of G2019S mice, significant behavioral consequences are relatively dormant until much later.

The NAc is critical for motivation and reward, and is involved in psychiatric disorders linked to stress including depression and anxiety (Carlezon et al., 2005; Bosch-Bouju et al., 2016; Han and Nestler, 2017). Social isolation and anhedonia, core features of depression, can be modeled in mice by chronic social defeat stress (CSDS), a paradigm of repeated physical subordination (Christoffel et al., 2011b). After undergoing CSDS, wild-type mice (WT) are either susceptible to the effects of chronic social stress, displaying significant social avoidance and anhedonia-like behaviors, which can be reversed by chronic antidepressants (Tsankova et al., 2006; Golden et al., 2011), or are resilient to CSDS, displaying social behavior similar to control (unstressed) mice. Importantly, behavioral resilience and susceptibility both represent

C. Menards' present address: Department of Psychiatry and Neuroscience, Faculty of Medicine, CERVO Brain Research Center, Université Laval, 2601 Chemin de la Canardière, Québec, QC G1J 2G3, Canada.

https://doi.org/10.1523/JNEUROSCl.1457-18.2018

Copyright $\odot 2018$ the authors $\quad 0270-6474 / 18 / 389701-12 \$ 15.00 / 0$ distinct programs of synaptic and other adaptations in striatal circuits in response to stress, including persistent modifications of synaptic strength and excitability (Christoffel et al., 2011a; Francis and Lobo, 2017). PD patients may respond differently to psychological stress (Smith et al., 2002; Austin et al., 2016), but how LRRK2-G2019S affects behavioral and synaptic adaptations to chronic social stress is unknown. We address this with a combination of behavioral and synaptic electrophysiological analyses of young adult Lrrk2-G2019S knock-in mice.

\section{Materials and Methods}

Mice. Lrrk2-G2019S knock-in (GSKI) mice were generated by Eli Lilly and were characterized previously (Matikainen-Ankney et al., 2016). Male homozygous GSKI mice (10-12 weeks old) and age- and strainmatched male WT mice were used in all behavioral analyses. Mice used in the study were congenic on C57BL/6NTac background and bred as homozygotes unless otherwise noted. The GSKI mice were backcrossed to WT C57BL/6NTac every fourth generation to prevent genetic drift. All WT mice were bred in Mount Sinai's vivarium and were reared under conditions that were identical to those of the GSKI mice. CD1 retired breeders (Charles River Laboratories) were $\geq 4$ months old for CSDS. LTP experiments were conducted on brains of male or female, 10- to 12-week-old homozygous GSKI and WT mice and when noted, 10- to 12-week-old heterozygous GSKI mice (male or female) expressing either tdTomato under control of the dopamine receptor 1a promoter [B6.Cg$\operatorname{Tg}$ (Drd1a-tdTomato)6Calak/J; strain 016204, The Jackson Laboratory] or eGFP under control of the dopamine receptor 2 promoter $[\mathrm{Tg}(\mathrm{Drd} 2-$ EGFP)S118Gsat; strain of origin: FVB/NTac] as described previously (Matikainen-Ankney et al., 2016). Genotypes were confirmed by PCR and sequencing. Animal procedures were approved by Mount Sinai's Institutional Animal Care and Use Committee and conformed to National Institutes of Health guidelines.

CSDS. Mice were subjected to $10 \mathrm{~d}$ CSDS (10 daily, 10 min defeat interactions with a novel CD1 aggressor), then social avoidance was assessed $24 \mathrm{~h}$ after the last defeat by a two-stage social interaction (SI) test as described previously (Golden et al., 2011). Unstressed control mice (GSKI and WT) were handled similarly, but were never exposed to aggressors. SI behavior was calculated as follows:

$$
\mathrm{SI}=\frac{t_{\text {present }}}{t_{\text {absent }}}
$$

Where $t_{\text {present }}$ and $t_{\text {absent }}$ are the times spent in the interaction zone with the novel aggressor present or absent, respectively. Mouse movement was continuously tracked (EthoVision 3.0, Noldus).

Sucrose preference and splash tests. Unstressed and post-CSDS WT and GSKI mice were subjected to a two-bottle choice paradigm (water or 1\% sucrose solution) for $48 \mathrm{~h}$. Amount of sucrose consumed was determined daily. For splash tests, a $10 \%$ sucrose solution was sprayed on the lower back and grooming behavior was captured using a video camera. Both tests were as described previously (Hodes et al., 2015).

Rotarod. Mice were tested on an accelerating rotarod daily for $4 \mathrm{~d}$. Each trial ( $n=4$ on Day $1, n=3$ on Days $2-4$ ) began at $4 \mathrm{rpm}$, steadily accelerating to $40 \mathrm{rpm}$ over $300 \mathrm{~s}$. The elapsed time before falling off the rotarod was recorded.

Elevated plus maze. Mice were placed in the center of an elevated plus maze. Mouse movement was tracked and scored automatically (EthoVision 11, Noldus). Cumulative time spent in open arms, closed arms or center was compared across groups as described previously (Gofflot et al., 2007).

Immunoblotting. Whole striatal lysates or striatal synaptoneurosomes were prepared from 10- to 12-week-old WT or GSKI mice as described previously (Nikitczuk et al., 2014; Matikainen-Ankney et al., 2016). Western blotting was performed by Shakti BioResearch and was independently verified in our laboratory. Primary antibodies to GluA1 (rabbit mAB 13185, 1:1000; Cell Signaling Technology; RRID:AB_2732897) or GluA2 (mouse mAB, 1:500; MABN1189, Millipore) were visualized with secondary antibodies (DyLight 800, Cell Signaling Technology; 
RRID:AB_10697505; and DyLight 680, Pierce) and imaged using a LICOR Odyssey CLX imager (LI-COR Biosciences). ImageJ (NIH) was used to determine protein levels via band intensity normalized to an actin loading control.

Immunohistochemistry. Perfused tissue sections through striatum were immunofluorescently labeled as described previously (MatikainenAnkney et al., 2016) with antibodies against GluA2 (1:1000; clone 6C4, BD Biosciences, catalog \#556341; RRID:AB_396373) and visualized with AlexaFluor 488-conjugated secondary antibodies (1:500; Jackson Immuno Research, catalog 715-545-150; RRID:AB_2340846). Single optical images were captured on a Zeiss LSM 780 confocal microscope. Immunofluorescent puncta were quantified using NIH ImageJ after a thresholding function was applied. Image acquisition and analysis were conducted by an experimenter blind to genotype.

Electrophysiology. Whole-cell patch-clamp recordings from SPNs were conducted on acute coronal slices from 10- to 12-week-old mice as described previously (Matikainen-Ankney et al., 2016). All recordings were conducted at $31^{\circ} \mathrm{C}$ in an immersion chamber containing Gabazine (GBZ; $10 \mu \mathrm{M}$ ). Recordings were made with a MultiClamp 700B amplifier (Molecular Devices) in both voltage- and current-clamp modes. Analog signals were low-pass filtered, digitized, and analyzed with pClamp10 software (Molecular Devices).

SPNs were visualized on an upright epifluorescence microscope (BX50WI, Olympus) using a 40× water-immersion lens and an IR-1000 infrared CCD monochrome video camera (DAGE MTI). For experiments using tdTomato or eGFP reporter mice, $\mathrm{D}_{1} \mathrm{R}$ - or $\mathrm{D}_{2} \mathrm{R}$-expressing SPNs were positively identified based on the presence of red or green fluorescence, respectively. Whole-cell recordings from SPNs were performed with glass micropipettes pulled from borosilicate glass capillaries using a P-87 micropipette puller (Sutter Instruments). The pipette resistance was 2-4 M $\Omega$. To record spontaneous EPSCs (sEPSCs), electrodes were filled with an intracellular solution containing the following (in $\mathrm{mm})$ : $124 \mathrm{~K}$-gluconate, $10 \mathrm{HEPES}, 10$ phosphocreatine di(Tris), 0.2 EGTA, $4 \mathrm{Mg}_{2}$ ATP, $0.3 \mathrm{Na}_{2} \mathrm{GTP}$, and (0.3\%) biocytin. Osmolarity of the intracellular solution was adjusted to $280-290 \mathrm{mOsm}$ and $\mathrm{pH}$ was adjusted to 7.3. sEPSCs were analyzed using Mini Analysis software with thresholds set at 6 (pA) for amplitude and 15 (pAms) for area. To identify SPNs electrophysiologically, after recording sEPSC activity in voltageclamp (5-10 min), we switched to current-clamp mode and applied a series of depolarizing current pulses (10 s interpulse intervals, $500 \mathrm{~ms}$ long pulses, $20 \mathrm{pA}$ current intervals), which allowed us to confirm SPN identity by characteristic action potential firing patterns described previously (Fino et al., 2008). Applied drugs were administered to the slice via a peristaltic pump (Cole-Parmer), and pump speed was adjusted so that solutions reached the slice $1.5 \mathrm{~min}$ after the start of application.

AMPAR rectification was assessed in NAc core SPNs by measuring evoked EPSC amplitudes at holding potentials from -80 to $+40 \mathrm{mV}$. D-APV $(40 \mu \mathrm{M})$ and GBZ $(10 \mu \mathrm{M})$ were bath-applied to block NMDAR and $\mathrm{GABA}_{\mathrm{A}} \mathrm{R}$ activity, respectively. The stimulating electrode was located $\sim 2 \mathrm{~mm}$ lateral to the NAc core. Rectification index (RI) was calculated as described previously (Goffer et al., 2013). SPNs in the NAc core were clamped at $0 \mathrm{mV}$ and the liquid junction potential was adjusted to reflect the true glutamatergic reversal potential. RI was calculated as follows:

$$
\mathrm{RI}=\frac{\left(\mathrm{I}_{-80 \mathrm{mV}}\right) /\left(80-\mathrm{E}_{\mathrm{rev}}\right)}{\left(\mathrm{I}_{+40 \mathrm{mV}}\right) /\left(40-\mathrm{E}_{\mathrm{rev}}\right)}
$$

where $I_{-80 \mathrm{mV}}$ and $I_{+40 \mathrm{mV}}$ are the absolute values of the average current amplitudes at -80 and $+40 \mathrm{mV}$, respectively (Goffer et al., 2013), and $E_{\text {rev }}$ is the reversal potential of each cell, calculated by linear interpolation. For this experiment the internal pipette solution contained the following (in mM): $115 \mathrm{~K}$-gluconate, $20 \mathrm{KCl}, 1.5 \mathrm{MgCl}_{2}, 10 \mathrm{HEPES}, 10$ phosphocreatine di(Tris), $2 \mathrm{Mg}_{2} \mathrm{ATP}, 0.5 \mathrm{Na}_{2} \mathrm{GTP}, 1 \mathrm{QX}-314$, (0.3\%) biocytin, and 0.1 spermine (Bowie and Mayer, 1995; Kamboj et al., 1995). AMPAR current-voltage ( $I-V)$ curves were recorded in mice $2-17 \mathrm{~d}$ after SI tests.

Functional $\mathrm{Ca}^{2+}$-permeable AMPAR (CP-AMPAR) responses were assessed in NAc core SPNs. Evoked AMPAR responses were determined at baseline before and after bath-application of the CP-AMPAR antago- nist 1-naphthyl acetyl spermine (NASPM; $200 \mu \mathrm{M}$ in 1:100 DMSO). An average of nine evoked EPSCs (baseline and after NASPM) for each cell were used to determine the ratio reported in Figure 2.

Long-term potentiation (LTP) of corticostriatal synapses was assessed by whole-cell recordings from SPNs in dorsomedial striatum. The stimulating electrode was located medially at the layer 6/white matter border where intact corticostriatal connections are preserved (MatikainenAnkney et al., 2016). This allowed greater certainty in stimulating corticostriatal afferents, which is confounded when stimulating in the NAc because of the convergence of excitatory afferents from many sources. LTP of corticostriatal synaptic strength was generated by pairing brief postsynaptic depolarization (to $0 \mathrm{mV}, 10 \mathrm{~min}$ ) with low-frequency afferent stimulation $(0.1 \mathrm{~Hz})$ as described previously (Feldman, 2000). For LTP experiments, the bath solution consisted of aCSF composed of the following (in mM): $117 \mathrm{NaCl}, 2.5 \mathrm{KCl}, 1.2 \mathrm{MgSO}_{4}, 3.5 \mathrm{CaCl}, 1.2$ $\mathrm{NaH}_{2} \mathrm{PO}_{4}, 24.9 \mathrm{NaHCO}_{3}$, and 20 glucose. The intracellular solution contained the following (in $\mathrm{mM}$ ): 120 Cs-methanesulfonate, 10 HEPES, 0.5 EGTA, $8 \mathrm{NaCl}, 5$ TEA-CL, $4 \mathrm{Mg}$-ATP, $0.4 \mathrm{NaGTP}$, and 10 phosphocreatine. Series resistance was measured continuously throughout with 5 $\mathrm{mV}$ and 100-ms-long hyperpolarizing pulses. If series resistance changed $>30 \%$ from the average baseline value, that cell would be discarded. Only one recording was performed per brain slice. Off-line analysis was performed using Clampfit (Molecular Devices) and Mini Analysis software (Synaptosoft).

Experimental design and statistical analyses. Statistical comparison of two groups was conducted using two-tailed Student's $t$ tests. For comparison of more than two groups, Bartlett's test for equal variance was performed; subsequent one-way ANOVAs were conducted to compare across groups with equal variances (Bartlett's $p>0.05$ ). Bonferroni post hoc tests were used for multiple comparisons where appropriate. To compare data from multiple groups over time, two-way ANOVA were performed. Fisher's exact test was used to compare CSDS outcomes contingent upon genotypes. Pearson bivariate correlations were used to assess predictive relationships between two variables. Cumulative probability distributions were compared using Kolmogorov-Smirnov tests. A $p$ value $<0.05$ was considered significant. Analyses used SAS statistical software v9.4 or GraphPad Software Prism v5.01. Data are presented as mean values \pm SEM. Numbers are listed as follows: $n=$ numbers of cells (numbers of mice) and are given in figure legends.

\section{Results}

\section{LRRK2-G2019S promotes resilience to chronic social defeat stress}

The G2019S mutation increases LRRK2 kinase activity 2- to 3-fold (West et al., 2005; Jaleel et al., 2007), and recent studies using pharmacological blockade of LRRK2 kinase activity or a knock-in mutation that renders LRRK2 kinase-dead confirm an abnormal gain-of-kinase function in the G2019S mice (MatikainenAnkney et al., 2016; Volta et al., 2017). We subjected young adult (10-week-old) male WT and GSKI mice to CSDS. In this paradigm (Fig. 1A), mice undergo 10 consecutive days of brief (10 $\mathrm{min}$ ) periods of social defeat through physical interaction and subordination by a larger aggressor. In between, mice maintain sensory contact with their aggressor through a perforated cagedivider. On the 11th day, socially stressed mice and unstressed controls are tested in a SI test. Briefly, mice are allowed to explore an arena in the absence and subsequent presence of a novel social target (Fig. 1A,B). An SI ratio is defined by time spent exploring the interaction zone when a social target is present divided by time in the interaction zone when the social target is absent. Mice with an SI ratio $<1$ are susceptible to CSDS, displaying social avoidance and other depression-like behaviors that can be reversed by chronic treatment with antidepressants (Berton et al., 2006; Tsankova et al., 2006), whereas mice with an SI ratio $>1$ do not display social avoidance, despite defeat experience, and are thus resilient to CSDS (Golden et al., 2011). 
A

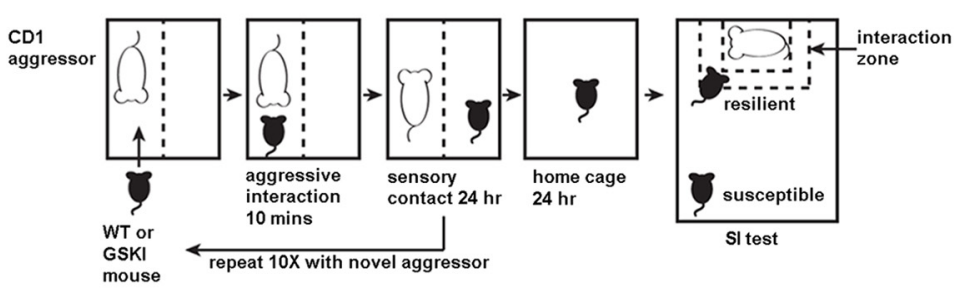

B

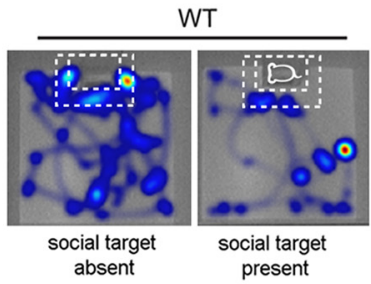

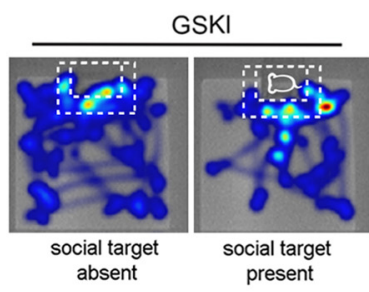

D

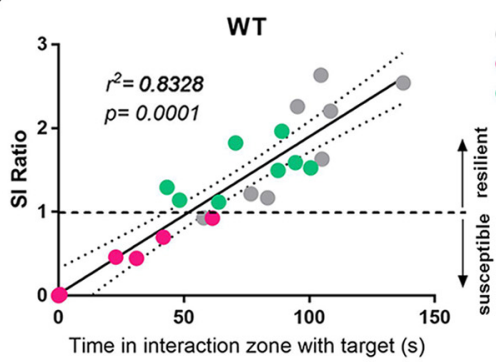

GSKI

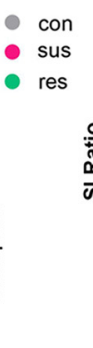

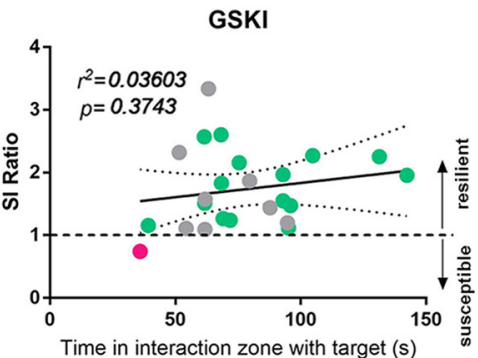

E

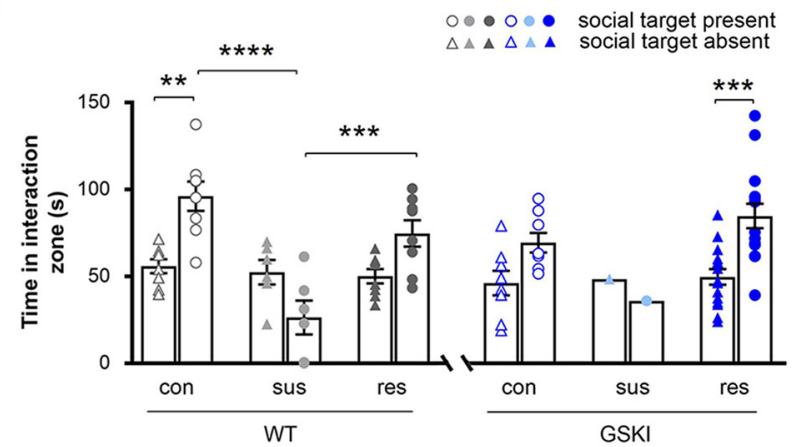

G

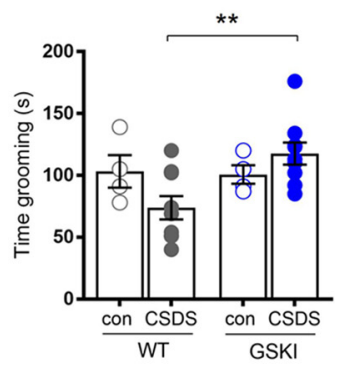

H

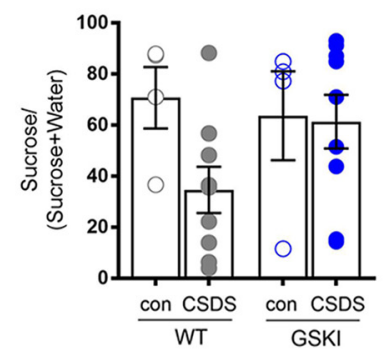

$\mathbf{F}$

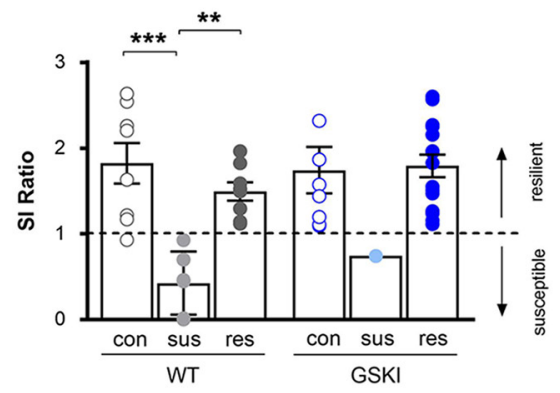

Figure 1. LRRK2-G2019S promotes resilience to CSDS. A, Schematic showing the 10-day CSDS paradigm and SI test. $\boldsymbol{B}$, Representative locomotion traces (red lines) of individual mice showing movement during the SI test. C, A significantly greater fraction of GSKI mice are resilient to CSDS ( $p=0.0309$, Fisher's exact test, $n=14$ WT and 16 GSKI). D, Scatter plots of unstressed (control) and stressed WT and GSKI SI ratios versus time spent in interaction zone (in seconds) when social target is present. There is a significant correlation between these variables for WT mice (left; $p=$ 0.0001 , Pearson correlation), but not for GSKI mice (right; $p=0.3743$, Pearson correlation). $\boldsymbol{E}$, Time in the interaction zone for WT mice (left, gray symbols) or GSKI mice (right, blue symbols) in the absence (triangles) or presence (circles) of a social target. WT control (con) and WT resilient (res) mice spend significantly more time in the interaction zone when the social target is present compared with susceptible (sus) WT mice ( $p=0.0001, F=11.41, n=8$ control, 14 CSDS; 8 WT res, 6 WT sus). Resilient GSKI mice also spend significantly more time in the interaction zone when a novel social target is present ( $p=0.0004, F=5.792, n=8$ control, 16 CSDS; 15 GSKI res, 1 GSKI sus). $\boldsymbol{F}$, The time spent in the interaction zone with a novel social target was normalized to time spent in the interaction zone without a social target to calculate the SI ratio. Comparisons of SI ratios across genotypes show that WT SI ratios were significantly decreased in susceptible but not resilient mice compared with unstressed controls, whereas all but one GSKI mouse exhibited resilient SI ratios ( $p=0.00001, F=6.607, n=8$ control mice per genotype, 6 WT susceptible, 8 WT resilient, $n=$ 1 GSKI susceptible and 15 GSKI resilient). $G$, After CSDS, GSKI mice spent significantly more time grooming during sucrose splash test in comparison with WT mice ( $p=0.0146, F=4.376, n=4$ con, 9 CSDS mice per genotype). $\boldsymbol{H}$, there were no significant differences between GSKI and WT mice in sucrose consumption either before or following CSDS ( $p=0.137, F=2.046, n=4$ con, 9 CSDS mice per genotype). One-way ANOVA with Bonferroni post hoc tests for multiple comparisons conducted in $\boldsymbol{E}-\boldsymbol{H}^{*}{ }^{*} p \leq 0.05,{ }^{* *} p \leq 0.01,{ }^{* * *} p \leq 0.001,{ }^{* * * *} p \leq 0.0001$. Error bars represent S.E.M.

Following CSDS, all mice were divided into resilient and susceptible subpopulations based on their SI ratios. WT mice $(n=$ 14) showed the expected frequencies (resilient: $n=8,57.1 \%$; susceptible: $n=6,42.9 \%$; Fig. $1 C, F$ ). In contrast, all GSKI mice that underwent CSDS $(n=15)$, except one, were resilient $(n=$ $14,93.8 \%)$, a significantly larger proportion of resilient animals in comparison with WT mice (Fig. $1 C, F$ ). In WT mice, SI ratios were correlated with time spent interacting with a novel social 
A

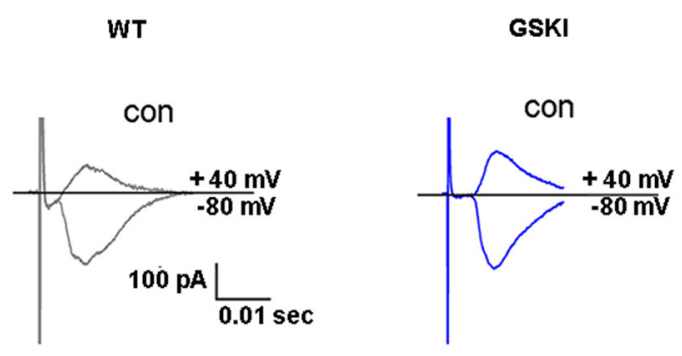

D

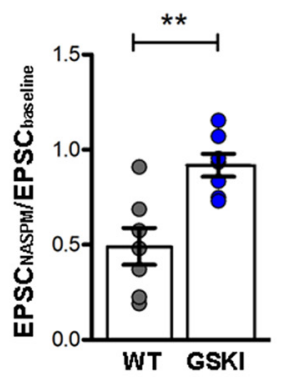

$\mathbf{F}$
B

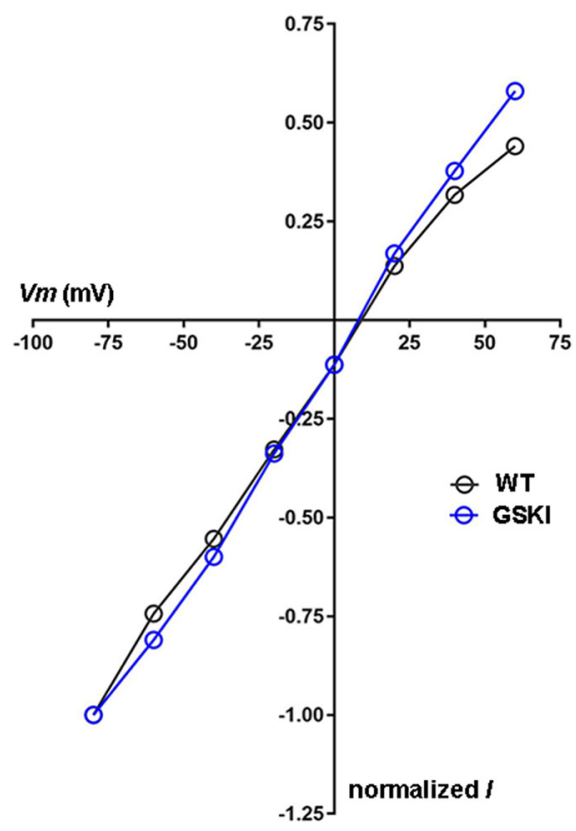

G

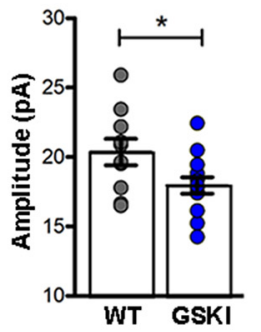

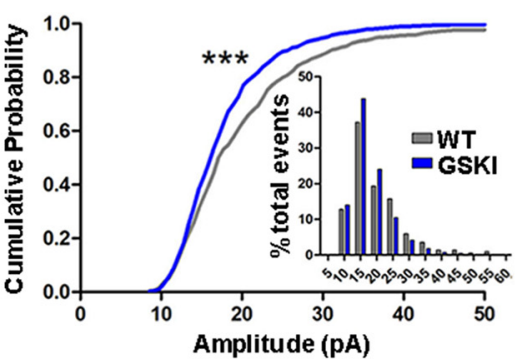

Figure 2. NAc synapses in G2019S mice lack CP-AMPARs at baseline. $A$, Sample traces for evoked AMPAR currents recorded from SPNs at two membrane potentials. Recordings were done on unstressed control (con) WT (gray) or GSKI (blue) mice. B, AMPAR I-V relationships for SPNs recorded from WT and GSKI control mice ( $n=8$ cells from 4 mice per genotype). C, Example traces showing AMPAR currents recorded from NAc synapses at baseline before (solid line) and after (dotted line) bath-application of the (P-AMPAR antagonist NASPM (200 $\mu$ M, 10 min). GSKI AMPAR currents were insensitive to NASPM. D, Plot showing quantification of data shown in C. EPSCs evoked in the presence of NASPM normalized to baseline (DMSO, 1:100). WT EPSC mean amplitude decreases after NASPM significantly more than GSKI. $p=0.0028, F=2.599, n=7(4)$ WT, $n=7(4)$ GSKI. Student's $t$ test. $E$, Sample traces of sEPSCs recorded from WT and GSKI NAc SPNs. $F$, Plots showing average amplitudes of sEPSCS. GSKI have a significantly lower average sEPSC amplitude ( $p=0.0351, F=1.967 ;$ WT: $n=10(4)$, GSKI: $n=13(5)$, Student's t test. G, Cumulative probability distributions of sEPSC amplitudes of the first 50 events per cell from WT (gray) or GSKI (blue) SPNs. Leftward shift is significant, $p=0.001$, WT $n=10(4)$, GSKI, $n=13(5)$, Kolmogorov-Smirnov test. Inset, Binned data of spine head widths. ${ }^{*} p \leq 0.05,{ }^{* *} p \leq 0.01,{ }^{* * *} p \leq 0.001$. Error bars represent S.E.M.

target (Fig. 1D), but in GSKI mice these two measures were uncorrelated (Fig. 1D). Together, these data suggest that the G2019S mutation disrupts normal behavioral responses to chronic social stress.

In the absence of CSDS, G2019S mice did not show altered social interaction behavior. There were no differences between WT and GSKI control (non-defeated) groups in time spent in the interaction zone when a social target was present (Fig. $1 E$ ) nor in mean SI ratios (Fig. $1 F$ ). Additionally, the abnormally high proportion of GSKI mice displaying resilience to chronic social defeat stress could not be attributed to general alterations in locomotor or exploratory activity conferred by the mutation because, in the absence of the social target, there were no significant differences between WT and GSKI mice in the amount of time spent exploring the interaction zone (Fig. 1E) or corner zones ( $p=0.5693, F=0.6799$, one-way ANOVA with Bonferroni post hoc comparisons), nor in average distance traveled as they explored the arena (WT mean: $\mu=1050 \pm 57.3 \mathrm{~cm}, n=23$; GSKI: $\mu=1027 \pm 36.31 \mathrm{~cm}, n=25, p=0.7263, F=2.291$, Student's $t$ test). A separate cohort of socially unstressed mice exposed to an accelerating rotarod test showed no significant differences in latency to fall compared with WT ( $p=0.4449$ for genotype interaction, $F=0.6208$, two-way repeated-measures ANOVA; $n=7$ WT, 8 GSKI). Together, these data indicate that the LRRK2G2019S mutation confers resilience to chronic social stress in young adult male mice, without affecting baseline levels of sociability, locomotion, or motor skill acquisition.

LRRK2-G2019S mice display altered levels of self-care following CSDS

Lack of self-care and anhedonia are also associated with depression in humans. Thus, we tested whether resilience of GSKI mice to CSDS was associated with altered self-care and anhedonia-like behaviors by subjecting WT and GSKI mice to a sucrose splash test, which measures self-care (Menard et al., 2017), and a $2 \mathrm{~d}$ sucrose preference test following CSDS. There were no differences between WT and GSKI mice in time grooming in the splash test before CSDS, but post-CSDS, GSKI mice spent significantly 
A

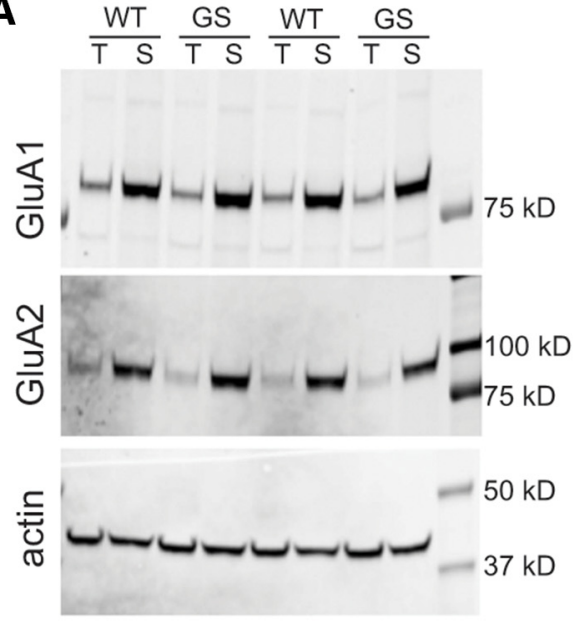

C

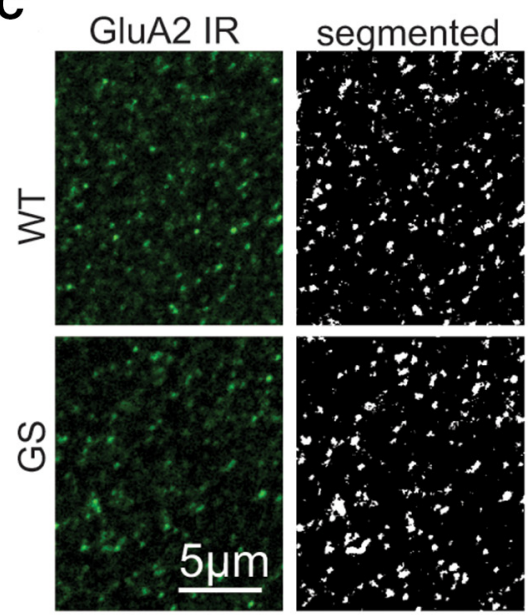

B

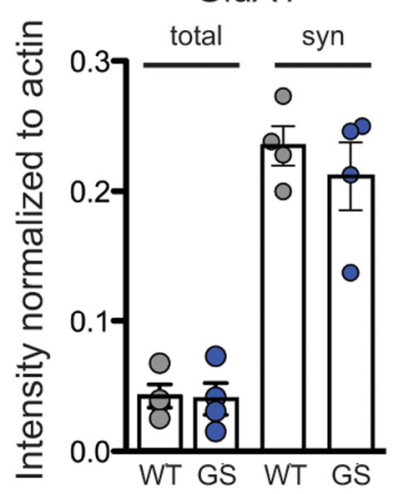

GluA2

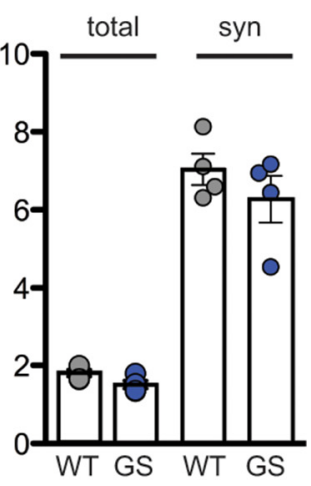

D

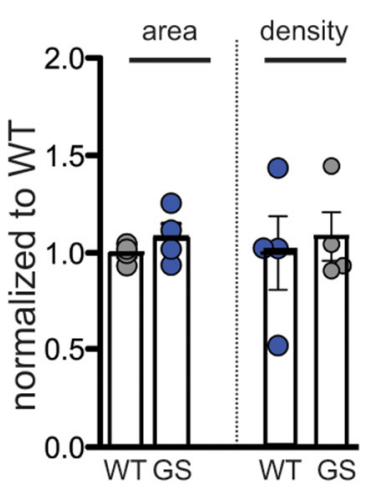

Figure 3. G2019S mutation does not alter glutamatergic receptor subunit expression. Blots for GluA1, GluA2, and actin protein levels in total $(\mathrm{T})$ and synaptic $(S)$ fractions $(\boldsymbol{A})$. $\boldsymbol{B}$, Dotted bar graphs showing quantification of data shown in $\boldsymbol{A}$; no significant differences seen in either GluA1 or GluA2 levels in total or synaptic fractions across genotypes. Within genotype, both GluA1 and GluA2 show significant synaptic enrichment compared with total fractions as expected (ANOVA, $p<0.0001 ; n=4$ per genotype). C, Single optical images acquired with a $63 \times$ objective (left) and after threshold was applied (right). Bar graph (D) of puncta area and density for WT and GSKI NAc GluA2. There were no significant differences between WT and GSKI, $n=3-4$ animals per genotype, $p=0.2955$ for area, and $p=0.7226$ for density.

greater time grooming in comparison with WTs (Fig. 1G). In contrast, there were no significant differences between genotypes in sucrose consumption either before or following CSDS (Fig. $1 H$ ). We also tested whether GSKI mice showed differences in anxiety-like behavior before or following CSDS by allowing GSKI and WT mice to explore an elevated plus-maze. However, neither in unstressed (control) cohorts nor in cohorts post-CSDS did we find any differences between genotypes in time spent in the open arms, center, or closed arms (open arms: $p=0.9108, F=0.1771$; center: $p=0.2138$, $F=1.618$; closed arms: $p=0.5217, F=0.7726 ; n=4$ control and 9 CSDS per genotype; one-way ANOVA with Bonferroni post hoc tests). Thus, GSKI mice respond differently than WT mice to CSDS, displaying robust resilience and lower levels of anhedonia-like behaviors. However, in the absence of CSDS, they do not show any differences with WT mice in these behavioral domains, nor in anxiety-like behavior.

Smaller contribution of calcium-permeable-AMPARs at NAc synapses in G2019S mice

AMPAR responses at striatal synapses are dynamic, displaying experience-dependent plasticity in a variety of behavioral and experimental contexts including social or restraint stress (Lim et al., 2012; Christoffel et al., 2015; Francis et al., 2015), cocaine (Britt et al., 2012; Ma et al., 2014; Khibnik et al., 2016), and LTP (Ma et al., 2018). Previous studies established that the G2019S mutation alters striatal glutamatergic synapses functionally and structurally during early postnatal life (Matikainen-Ankney et al., 2016). This suggests that AMPAR responses in the NAc differ from WT synapses, thus possibly altering the normal distribution of behavioral responses to social stress. To investigate this, we compared AMPAR responses at WT and GSKI NAc synapses at baseline and following CSDS as a potential basis for the preponderance of resilient GSKI mice following CSDS.

AMPARs that lack edited GluA2 are calcium-permeable (CP) and display nonlinear AMPAR $I-V$ relationships because of inward rectification at positive membrane voltages (Hume et al., 1991; Verdoorn et al., 1991). We interrogated baseline AMPAR-mediated $I-V$ relationships by whole-cell recording from NAc SPNs from control (non-defeated) WT or GSKI mice. We found that WT synapses displayed more inwardly rectifying responses at baseline in comparison with GSKI synapses, which displayed linear $I-V$ curves (Figs. $2 A, B$ ), suggesting that the contribution of CP-AMPARs to baseline synaptic responses in the NAc differed between WT and GSKI synapses. We then probed functionally for the relative content of CP-AMPARs at NAc synapses by measuring the sensitivity of evoked AMPAR-EPSCs (eEPSCs) to NASPM, a selective antagonist of CP-AMPARs (Isaac et al., 2007). In WT mice, NASPM significantly decreased the average amplitude of eEPSC, whereas in GSKI mice, the average amplitude of eEPSCs at NAc synapses was largely unaffected by NASPM (Fig. $2 C, D)$. We asked further whether $\mathrm{D}_{1} \mathrm{R}$ - or $\mathrm{D}_{2} \mathrm{R}$-SPNs differed in their NASPM sensitivity by repeating these experiments on $D_{1} R$ SPNs (tdTomato-positive) or putative $\mathrm{D}_{2} \mathrm{R}-\mathrm{SPNs}$ (tdTomatonegative; Matikainen-Ankney et al., 2016), but found no significant SPN subtype-specific differences in NASPM sensitivity [normalized eEPSC average amplitude for GSKI D $\mathrm{D}_{1}$-SPNs: $\mu=1.306 \pm 0.314, n=6(4)$; GSKI D 2 R-SPNs: $\mu=0.464 \pm$ $0.195, n=4(4) ; p=0.0811, F=3.896$, Student's $t$ test]. Insensitivity to NASPM suggests that GSKI synapses in the NAc mostly lack CP-AMPARs. This was not due to overt differences between genotypes in expression levels of AMPAR subunits, because Western blot analyses of total striatal lysates and synaptoneurosomes and immunofluorescence analyses showed that WT and GSKI mice expressed similar levels of GluA1 and GluA2 (Fig. 3) the major AMPAR subunits in striatum (Reimers et al., 2011). Previous studies have shown that the lack of CP-AMPARs corresponds to lower sEPSC amplitudes (Liu and Cull-Candy, 2000). Consistent with this, whole-cell recording from WT or GSKI SPNs in the NAc showed that GSKI sEPSC amplitudes were significantly lower in comparison with WTs (Fig. $2 E-G$ ). There was no significant difference between genotypes in frequency [WT: 
A

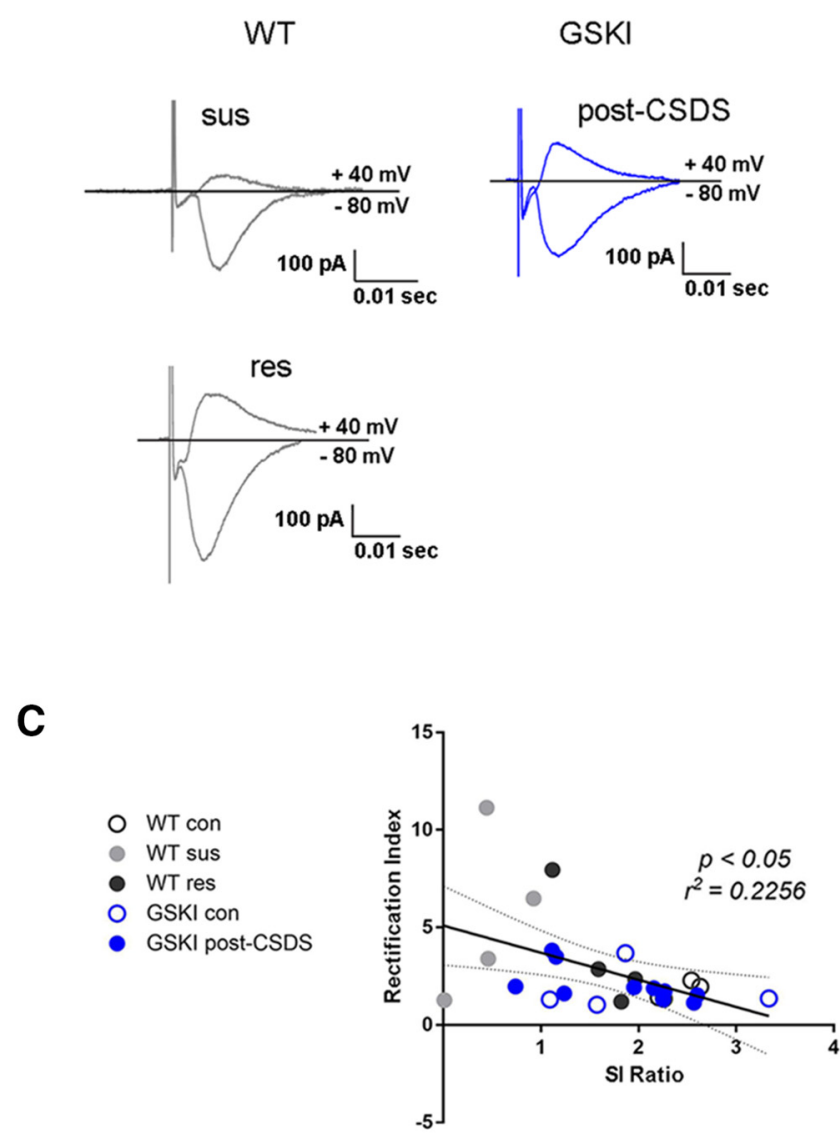

B

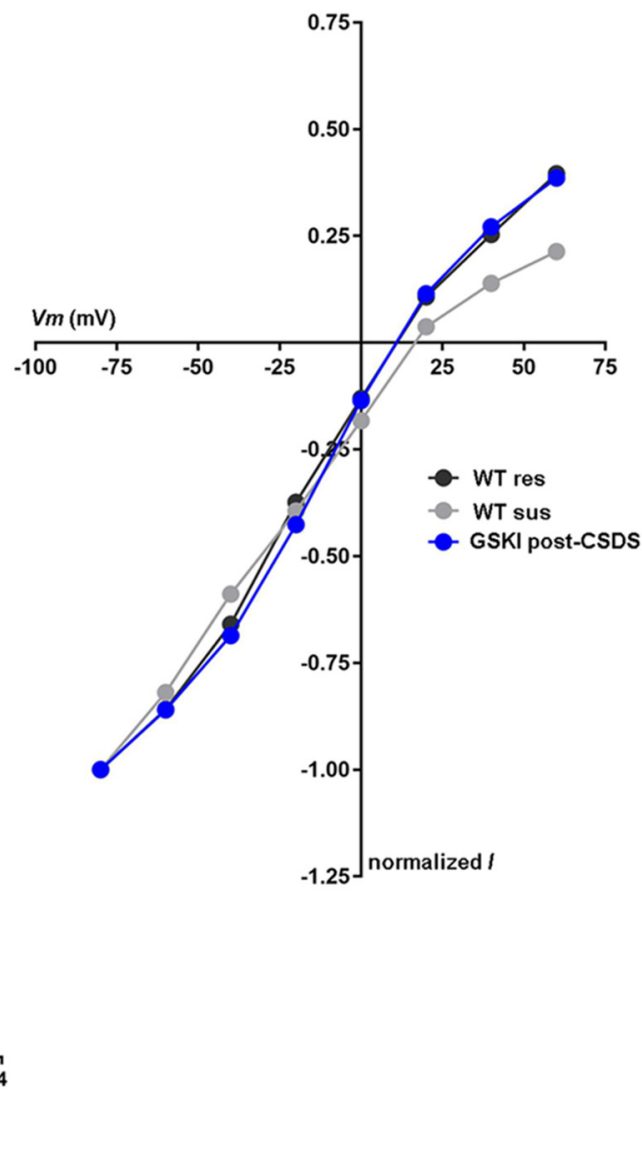

Figure 4. GSKI SPNs fail to accumulate CP-AMPARs post-CSDS. A, Sample traces of evoked AMPAR currents recorded from NAc SPNs at two membrane potentials. Recordings were done on mice post-CSDS from WT (gray) or GSKI (blue). B, AMPAR I-V relationships for SPNs recorded from WT susceptible (sus) or resilient (res) or from GSKI mice post-CSDS. Susceptible WT mice show pronounced inward rectification, as expected, while GSKI mice and resilient WT mice show mostly linear $I-V$ curves. $C$, Scatter plot of SI ratio versus rectification index. Linear regression analysis revealed a significant inverse correlation ( $p=0.0142, r^{2}=0.2256$, Pearson correlation, $n=26$ mice). Mice with the three highest and three lowest SI ratios from each group were selected for recording. $n=8-20$ cells from 4 to 10 mice per group.

$\mu=2.163 \pm 0.0237, n=9(4)$; GSKI: $\mu=2.487 \pm 0.559, n=$ 15(5), $p=0.6697, F=9.263$, Student's $t$ test]. Together, these experiments suggest that mutant striatal synapses are dominated at baseline by calcium-impermeable AMPAR subunits, a significantly altered AMPAR subunit stoichiometry in comparison with WT synapses.

Given that mutant NAc synapses displayed a significantly different AMPAR composition at baseline, we next probed how AMPAR stoichiometry changed functionally in response to CSDS. In WT mice, those that are susceptible to CSDS acquire more inwardly rectifying AMPARs and gain NASPM sensitivity in comparison with those that are resilient (Vialou et al., 2010; Lim et al., 2012), reflecting a greater incorporation of synaptic CP-AMPARs (Jonas et al., 1994; Bowie and Mayer, 1995; Kamboj et al., 1995). As expected, SPNs from susceptible WT mice exhibited greater inwardly rectifying AMPARs compared with those of resilient WT mice (Fig. 4A,B). In GSKI mice that underwent CSDS, SPNs displayed $I-V$ curves that were similar to WT resilient mice (Fig. 4B), highlighting a similar synaptic hallmark of resiliency between mutant and WT mice. Additionally, we found a significant inverse correlation between average RI and SI ratio across defeat-experienced and control groups of each genotype (Fig. 4C). For WT mice, this suggests that synaptic incorporation of CP-AMPARs drives, at least in part, susceptibility to CSDS
(Vialou et al., 2010). Conversely, the absence of significant numbers of susceptible GSKI mice may reflect mutant glutamatergic striatal synapses that mostly lack CP-AMPARs and are unable to incorporate them.

\section{Loss of bidirectional synaptic plasticity at corticostriatal synapses in GSKI mice}

Striatal glutamatergic synapses on SPNs are normally capable of bidirectional changes in strength. LTP requires postsynaptic NMDARs and is associated with postsynaptic incorporation of CP-AMPARs (Kreitzer and Malenka, 2008; Ma et al., 2018). Long-term depression (LTD) requires postsynaptic mGluR signaling for induction, but is expressed presynaptically through endocannabinoid receptor 1 (eCB1)- or Adenosine $\mathrm{A}_{1}$ receptordependent reduction in the probability of neurotransmitter release from corticostriatal terminals (Kreitzer and Malenka, 2008; Trusel et al., 2015). The altered AMPAR composition at NAc synapses and the lack of inwardly rectifying modifications following CSDS suggest that synaptic plasticity mechanisms that depend on postsynaptic AMPAR composition and trafficking (e.g., LTP) are fundamentally altered in GSKI mice. To test this, we first confirmed that WT corticostriatal synapses display NMDARdependent LTP using an LTP-pairing protocol in slices taken from animals aged 3 weeks and 10 weeks (Feldman, 2000; Fig. 
A

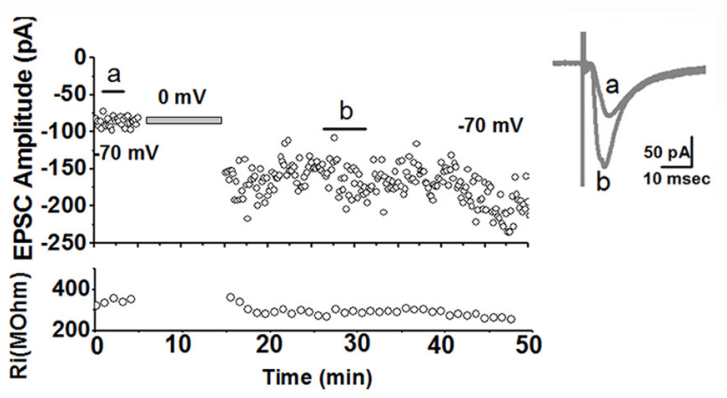

B

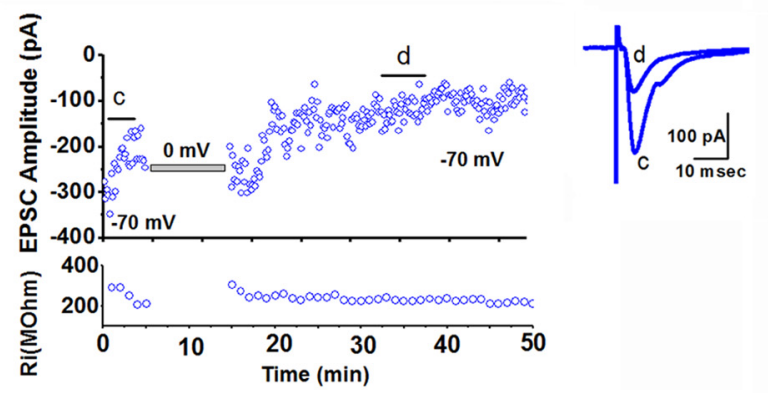

C

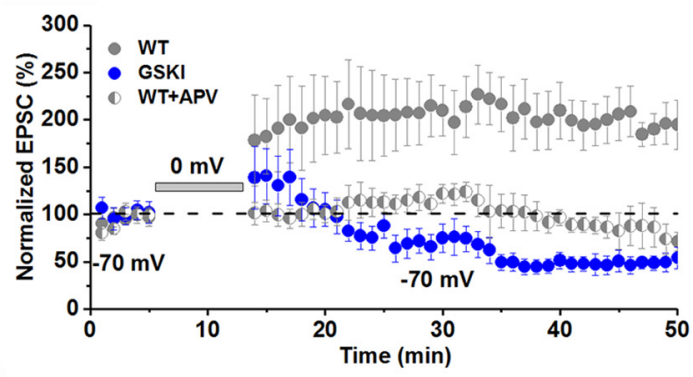

D

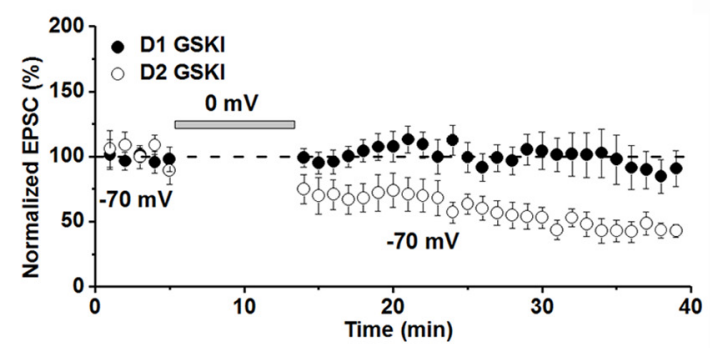

D1 GSKI

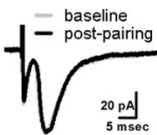

D2 GSKI

$\mathbf{E}$

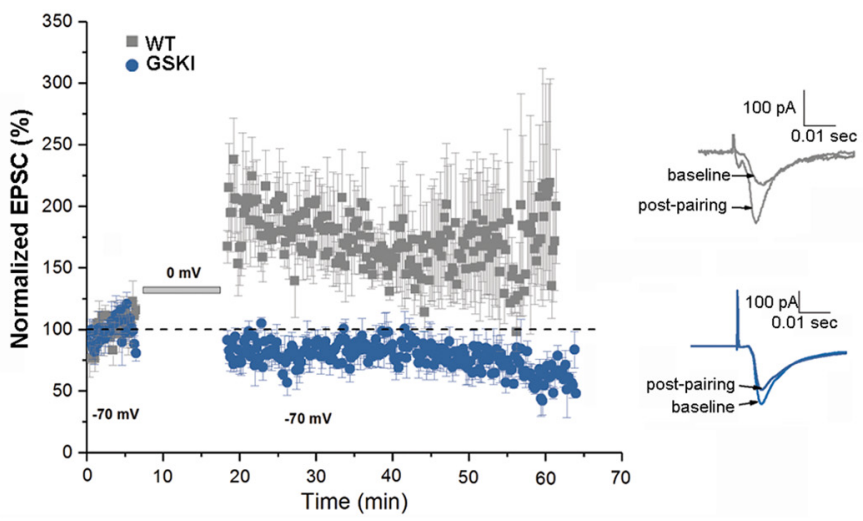

Figure 5. Subtype-specific disruption in bidirectional synaptic plasticity in G2019S SPNs. A, WT SPNs recorded in dorsomedial striatum from P21 mice. Plots show EPSC amplitudes and input resistance as a function of time. LTP was induced by pairing brief depolarization (horizontal bar, $0 \mathrm{mV}$ ) with continuous corticostriatal presynaptic stimulation $(0.1 \mathrm{~Hz})$. Sample traces are averages of EPSCs from representative areas in the plot graph (a, baseline; b, post-pairing). $B$, GSKI SPNs recorded in dorsomedial striatum from P21 mice. The LTP protocol abnormally produced LTD. Plot shows reduction of EPSC amplitudes following pairing (horizontal bar, $0 \mathrm{mV}$ ). Sample traces are averages of EPSCs from representative areas in the plot (c, baseline; $d$, post-pairing). $C$, Normalized EPSC amplitudes of WT (gray) or GSKI (blue) SPNs from P21 mice at baseline and following pairing (horizontal bar, $0 \mathrm{mV}$ ). Data are normalized to WT baseline [ $n=6(3)]$, GSKI $[n=6(3) ; p=0.0001$, $F=332.6$ for genotype main effect]. Symbols represent the averages of 6 trials. LTP induced in WT SPNs was NMDAR-dependent (half-grey, half-white symbols), because it was blocked completely by APV [40 $\mu \mathrm{m} ; n=4(2), p=0.0001, F=773.1$, for pharmacologic main effect]. $\boldsymbol{D}$, In response to the LTP-pairing protocol, GSKI $D_{1} R$-SPNs remain unchanged from baseline [black circles, normalized traces of $D_{1} R-S P N s ; n=6(5), p=0.0001, F=33.05$ for genotype main effect]. In contrast, $D_{2} R$-SPNs show LTD [white circles, normalized traces of $D_{2} R-S P N s ; n=3(2)$ ]. Representative traces show average EPSCs before (gray) and after (black) applying the LTP-induction protocol to $D_{1} R$ - or $D_{2} R-S P N s$. Two-way ANOVAs were conducted in $\boldsymbol{C}$ and $\boldsymbol{D}$. $\boldsymbol{E}$, Graph showing the effect of LTP-protocol on P70 WT and GSKI SPNs (both $D_{1}$ R and D R RPNs). LTP was induced in all WT cells [gray squares; $n=4(4)$ ), whereas the LTP-protocol abnormally elicited modest LTD in GSKI SPNs [blue circles; $n=5(3), p=0.0001, F=175.3$ for genotype main effect]. Insets, Averaged EPSC traces during baseline and after pairing. GBZ (10 $\mu \mathrm{m})$ was applied throughout. Error bars indicate SEM.

$5 A, C, E)$. In contrast, the same LTP-pairing protocol applied to GSKI SPNs failed to induce LTP, and instead abnormally elicited LTD at both ages (Fig. $5 B, C, E$ ). To determine whether such abnormally elicited LTD was specific to $\mathrm{D}_{1} \mathrm{R}$ - or $\mathrm{D}_{2} \mathrm{R}-\mathrm{SPNs}$, we repeated these experiments in GSKI mice that were crossed to reporter lines of mice expressing either tdTomato in $\mathrm{D}_{1} \mathrm{R}-\mathrm{SPN}$ or expressing eGFP in $\mathrm{D}_{2} \mathrm{R}-\mathrm{SPN}$. We found that both $\mathrm{D}_{1} \mathrm{R}$ - and $\mathrm{D}_{2} \mathrm{R}-\mathrm{SPN}$ failed to display LTP, but only the $\mathrm{D}_{2} \mathrm{R}-\mathrm{SPN}$ s exhibited abnormal LTD elicited by the LTP-pairing protocol (Fig. $5 D)$. Together, these data reveal that GSKI striatal synapses exhibit abnormally unidirectional synaptic plasticity.

\section{Discussion}

We combined behavioral and electrophysiological interrogation of knock-in mice carrying the PD-associated Lrrk2-G2019S mutation to demonstrate that young adult male G2019S mice are unusually resilient to chronic social defeat stress, a paradigm that models core features of depression in humans (Kudryavtseva et al., 1991; Berton et al., 2006; Krishnan et al., 2008). Despite daily physical subordination, mutant mice failed to exhibit social avoidance and anhedonia-like behaviors. This is striking because a significant proportion of WT mice undergoing CSDS become 
stress-susceptible to social defeat, displaying prominent social avoidance (Fig. 1; Golden et al., 2011). We found that glutamatergic synapses in the NAc of mutant mice lacked functional CP-AMPARs, and following CSDS, failed to accumulate inwardly rectifying AMPAR responses characteristic of susceptible mice (Vialou et al., 2010). Further, persistent synaptic modifications of corticostriatal synaptic strength were perturbed in mutant mice. Both $\mathrm{D}_{1} \mathrm{R}$ - and $\mathrm{D}_{2} \mathrm{R}-\mathrm{SPN}$ in the mutants were unable to express LTP, with the latter abnormally expressing LTD following an LTP-induction protocol. Together, these data indicate that the G2019S mutation exerts significant effects on behavioral responses to social stress in young adulthood, which in turn may reflect mutant synapses constrained in their ability to undergo experience-dependent plasticity (Fig. 6).

Our results provide important new insight into when and in what ways the G2019S mutation affects complex behaviors, and suggest that the G2019S mutation exerts a lifelong influence on brain and behavior. This is an important distinction because it is often tacitly assumed that in human late-onset $\mathrm{PD}$, the time at which genetic or other causative factors first co-opt cell and circuit function is at onset of the prodromal phase (Hawkes, 2008), which commences in midlife before motor abnormalities (Hawkes et al., 2010; Pont-Sunyer et al., 2015). Despite strong evidence from mouse models that G2019S significantly alters corticostriatal synaptic structure and function by three postnatal weeks (Matikainen-Ankney et al., 2016; Volta et al., 2017), previous behavioral investigations of G2019S knock-in or overexpression mutants have largely failed to uncover significant behavioral phenotypes, other than mild hyperkinesis, in mice younger than 10-12 months of age (Longo et al., 2014; Volta et al., 2015, 2017; Yue et al., 2015; Lim et al., 2018). Our data suggest that robust behavioral abnormalities become evident at young ages in mutants only after a significant, experience-dependent challenge, such as that sustained by repeated bouts of social stress. Indeed, we found that in the absence of CSDS, the G2019S mice were indistinguishable from WT mice across a variety of behavioral domains, including social interaction, anxiety, exploratory/locomotor activity, self-care, anhedonia-like behavior, and motor skill learning. That the young mutant mice displayed robust resilience, not susceptibility, to CSDS was unexpected given that psychiatric symptoms, including depression and anxiety, are prominent non-motor symptoms of PD (Ishihara and Brayne, 2006; Gaig et al., 2014). This may indicate an early, initially adaptive albeit abnormal coping mechanism imparted by the mutation that over time becomes maladaptive, leading to prodromal psychiatric symptoms and subsequent motor dysfunction. The neurobiology underlying any such transition is unknown, but may involve progressive G2019S-driven pathological changes to dopamine (Ramonet et al., 2011; Yue et al., 2015; Pan et al., 2017; Volta et al., 2017; Xiong et al., 2018), serotonin (Lim et al., 2018), or other systems colluding with the mutation-driven abnormal- ities in glutamatergic synaptic function. Recently, transgenic mice overexpressing human LRRK2-G2019S were described as displaying anxiety and depression-like behaviors starting at 10 months of age (Lim et al., 2018). These data are difficult to interpret however, because overexpression of WT or mutant LRRK2 is toxic to neurons (Skibinski et al., 2014) and control mice overexpressing human WT LRRK2 were not examined. It will also be important in future studies to examine behavioral consequences of G2019S in young female mice. Synaptic abnormalities in young male and female mutants have been identical (Matikainen-Ankney et al., 2016), so behavioral responses may be similar as well.

Our data also reveal baseline synaptic abnormalities in young adult mutants that may underlie altered behavioral adaptations to stress or other challenges. We found that NAc synapses in unstressed control mutant mice lacked functional CP-AMPARs as indicated by AMPAR currents that were insensitive to NASPM and displayed linear $I-V$ relationships. This suggests that synaptic trafficking of CP-AMPARs is impaired in mutants, because expression levels of GluA1 and GluA2 were similar between genotypes. Such a deficit would be expected to impact the acquisition of social avoidance following CSDS, and, more broadly, could have potential relevance to other striatal circuit-based PD-related phenotypes. It has been shown that NAc synapses of susceptible mice can be distinguished from those of resilient mice by the accumulation of inwardly rectifying, NASPM-sensitive AMPAR currents (Vialou et al., 2010), an indication of synaptic incorporation of CPAMPARs (Isaac et al., 2007). Our data were consistent with this, as susceptible WT mice acquired inwardly rectifying AMPARs as expected, whereas GSKI mice post-CSDS displayed linear AMPAR I-V curves similar to resilient WT mice. Further, correlation analyses suggest that incorporation of CP-AMPARs drives social 
avoidance following CSDS (Fig. 4C; Vialou et al., 2010), which may indicate that for young adult GSKI mice, it is the inability to acquire CP-AMPARs that renders them, at least in part, incapable of social avoidance following CSDS (Fig. 6). Although this remains to be tested, resilience to CSDS is not simply an absence of susceptibility; both resilience and susceptibility to CSDS are active processes of genetic, epigenetic, biochemical, and synaptic adaptations involving several interconnected cortical and subcortical brain structures including the NAc (Russo et al., 2012). Further studies will be required to show whether resilience displayed by GSKI mice reflects similar or novel adaptations to those of resilient WT mice.

An AMPAR trafficking defect could also underlie the inability of GSKI corticostriatal synapses to express LTP (Fig. 6). It has been shown that electrical stimulation of corticostriatal afferents paired with depolarization of dorsomedial SPNs elicited NMDAR-dependent LTP associated with synaptic incorporation of CP-AMPARs; when such LTP was blocked with NMDAR antagonists, an eCB1-dependent LTD resulted instead (Ma et al., 2018). Our observation in the mutants that LTD resulted when LTP failed is consistent with the idea that postsynaptic LTP and presynaptic LTD could be elicited at SPN synapses contemporaneously, with LTP dominating unless blocked (Lovinger, 2010; Augustin et al., 2014; Ma et al., 2018). Other studies have shown that LTD is generally harder to elicit in $\mathrm{D}_{1} \mathrm{R}-\mathrm{SPNs}$ (Kreitzer and Malenka, 2007), requiring the presence of $D_{1} R$-antagonists (Shen et al., 2008) or muscarinic $\mathrm{M}_{4}$ receptor agonists (Shen et al., 2015) during induction, which might explain why abnormal LTD was readily elicited only in mutant $\mathrm{D}_{2} \mathrm{R}$-SPNs. In general, circuitspecific enhancement of glutamatergic transmission in the NAc has been associated with depression-like behavior after chronic stress (Vialou et al., 2010; Lim et al., 2012; Bagot et al., 2015; Christoffel et al., 2015). The inability of corticostriatal inputs to elicit, at baseline, long-lasting strengthening of synaptic drive onto either $\mathrm{D}_{1} \mathrm{R}$ - or $\mathrm{D}_{2} \mathrm{R}$ - SPNs in the mutants may be contributing to their pronounced resilience following CSDS, though further studies are warranted. A limitation of our study is that synaptic plasticity deficits were investigated in dorsomedial striatum, not in the NAc. Although this gave us control over the identity of the presynaptic inputs that were potentiated, pathwayspecific analyses of NAc inputs, by optogenetics for example, will be required to verify plasticity deficits at identified NAc synapses. This is potentially important, because differences between dorsal and ventral striatum in transmitter-specific coupling have been described that could affect plasticity (Marcott et al., 2018). On the other hand, there is evidence for involvement of dorsal striatum in depression-like behaviors in mice and humans. Previous studies in mice have shown that CSDS increases expression of the transcription factor delta-FosB in dorsomedial striatum (Cooper et al., 2017) and functional imaging studies in humans show altered dorsal striatal connectivity in patients with depression (Furman et al., 2011; Gabbay et al., 2013; Kerestes et al., 2015). These data suggest that synaptic and cellular plasticity mechanisms in dorsomedial striatum require further investigation in the context of depression and anhedonia-like behaviors.

Molecularly, mutant LRRK2 may affect AMPAR trafficking through its phospho-targets Rab8a (Steger et al., 2016), a small GTPase that mediates synaptic insertion of AMPAR subunits (Gerges et al., 2004; Brown et al., 2007), or N-ethylmaleimidesensitive factor (NSF; Belluzzi et al., 2016), which controls GluA2 insertion (Nishimune et al., 1998). Additionally, LRRK2 binds to the regulatory subunit of cAMP-dependent protein kinase A (PKA) and negatively regulates its activity (Parisiadou et al., 2014;
Greggio et al., 2017). This pathway is an essential signaling pathway for bidirectional plasticity in both striatal subtypes (Lerner and Kreitzer, 2012; Tritsch et al., 2012; Augustin et al., 2014). Thus, the loss of bidirectional plasticity in both $\mathrm{D}_{1} \mathrm{R}$ - and $\mathrm{D}_{2} \mathrm{R}$ SPNs in G2019S mice might reflect a common, mutation-driven alteration in PKA signaling that mechanistically impairs insertion of CP-AMPARs under conditions of behavioral and synaptic plasticity (Fig. 6).

Our study reveals a novel, LRRK2-dependent mechanism that supports behavioral resilience, alters glutamate receptor signaling and underlies abnormal synapse plasticity in young adult mice. The actions of mutant LRRK2 in young animals suggest that there may also be predictable differences in responses to stress in humans carrying the G2019S mutation, long before the canonical PD motor symptoms appear. Additionally, the data suggest that striatal behavioral plasticity may be altered fundamentally by the presence of the G2019S mutation in ways that would be expected to impact treatment strategies for non-motor symptoms like depression that accompany PD.

\section{References}

Augustin SM, Beeler JA, McGehee DS, Zhuang X (2014) Cyclic AMP and afferent activity govern bidirectional synaptic plasticity in striatopallidal neurons. J Neurosci 34:6692-6699. CrossRef Medline

Austin KW, Ameringer SW, Cloud LJ (2016) An integrated review of psychological srtress in Parkinson's disease: biological mechanisms and symptom and health outcomes. Parkinsons Dis 2016:9869712. CrossRef Medline

Bagot RC, Parise EM, Peña CJ, Zhang HX, Maze I, Chaudhury D, Persaud B, Cachope R, Bolaños-Guzman CA, Cheer J, Deisseroth K, Han MH, Nestler EJ (2015) Ventral hippocampal afferents to the nucleus accumbens regulate susceptibility to depression. Nat Commun 6:7062. CrossRef Medline

Belluzzi E, Gonnelli A, Cirnaru MD, Marte A, Plotegher N, Russo I, Civiero L, Cogo S, Carrion MP, Franchin C, Arrigoni G, Beltramini M, Bubacco L, Onofri F, Piccoli G, Greggio E (2016) LRRK2 phosphorylates presynaptic $N$-ethylmaleimide sensitive fusion (NSF) protein enhancing its ATPase activity and SNARE complex disassembling rate. Mol Neurodegener 11:1. CrossRef Medline

Berton O, McClung CA, Dileone RJ, Krishnan V, Renthal W, Russo SJ, Graham D, Tsankova NM, Bolanos CA, Rios M, Monteggia LM, Self DW, Nestler EJ (2006) Essential role of BDNF in the mesolimbic dopamine pathway in social defeat stress. Science 311:864-868. CrossRef Medline

Bosch-Bouju C, Larrieu T, Linders L, Manzoni OJ, Layé S (2016) Endocannabinoid-mediated plasticity in nucleus accumbens controls vulnerability to anxiety after social defeat stress. Cell Rep 16:1237-1242. CrossRef Medline

Bowie D, Mayer ML (1995) Inward rectification of both AMPA and kainate subtype glutamate receptors generated by polyamine-mediated ion channel block. Neuron 15:453-462. CrossRef Medline

Britt JP, Benaliouad F, McDevitt RA, Stuber GD, Wise RA, Bonci A (2012) Synaptic and behavioral profile of multiple glutamatergic inputs to the nucleus accumbens. Neuron 76:790-803. CrossRef Medline

Brown TC, Correia SS, Petrok CN, Esteban JA (2007) Functional compartmentalization of endosomal trafficking for the synaptic delivery of AMPA receptors during long-term potentiation. J Neurosci 27:13311-13315. CrossRef Medline

Carlezon WA Jr, Duman RS, Nestler EJ (2005) The many faces of CREB. Trends Neurosci 28:436-445. CrossRef Medline

Christoffel DJ, Golden SA, Dumitriu D, Robison AJ, Janssen WG, Ahn HF, Krishnan V, Reyes CM, Han MH, Ables JL, Eisch AJ, Dietz DM, Ferguson D, Neve RL, Greengard P, Kim Y, Morrison JH, Russo SJ (2011a) I kinase regulates social defeat stress-induced synaptic and behavioral plasticity. J Neurosci 31:314-321. CrossRef Medline

Christoffel DJ, Golden SA, Russo SJ (2011b) Structural and synaptic plasticity in stress-related disorders. Rev Neurosci 22:535-549. CrossRef Medline

Christoffel DJ, Golden SA, Walsh JJ, Guise KG, Heshmati M, Friedman AK, Dey A, Smith M, Rebusi N, Pfau M, Ables JL, Aleyasin H, Khibnik LA, 
Hodes GE, Ben-Dor GA, Deisseroth K, Shapiro ML, Malenka RC, IbanezTallon I, Han MH, Russo SJ (2015) Excitatory transmission at thalamostriatal synapses mediates susceptibility to social stress. Nat Neurosci 18: 962-964. CrossRef Medline

Cooper SE, Kechner M, Caraballo-Pérez D, Kaska S, Robison AJ, MazeiRobison MS (2017) Comparison of chronic physical and emotional social defeat stress effects on mesocorticolimbic circuit activation and voluntary consumption of morphine. Sci Rep 7:8445-8459. CrossRef Medline

Feldman DE (2000) Timing-based LTP and LTD at vertical inputs to layer II/III pyramidal cells in rat barrel cortex. Neuron 27:45-56. CrossRef Medline

Fino E, Deniau JM, Venance L (2008) Cell-specific spike-timing-dependent plasticity in GABAergic and cholinergic interneurons in corticostriatal rat brain slices. J Physiol 586:265-282. CrossRef Medline

Francis TC, Lobo MK (2017) Emerging role for nucleus accumbens medium spiny neuron subtypes in depression. Biol Psychiatry 81:645-653. CrossRef Medline

Francis TC, Chandra R, Friend DM, Finkel E, Dayrit G, Miranda J, Brooks JM, Iñiguez SD, O’Donnell P, Kravitz A, Lobo MK (2015) Nucleus accumbens medium spiny neuron subtypes mediate depression-related outcomes to social defeat stress. Biol Psychiatry 77:212-222. CrossRef Medline

Furman DJ, Hamilton JP, Gotlib IH (2011) Frontostriatal functional connectivity in major depressive disorder. Biol Mood Anxiety Disord 1:11. CrossRef Medline

Gabbay V, Ely BA, Li Q, Bangaru SD, Panzer AM, Alonso CM, Castellanos FX, Milham MP (2013) Striatum-based circuitry of adolescent depression and anhedonia. J Am Acad Child Adolesc Psychiatry 52:628-641.e13. CrossRef Medline

Gaig C, Vilas D, Infante J, Sierra M, García-Gorostiaga I, Buongiorno M, Ezquerra M, Martí MJ, Valldeoriola F, Aguilar M, Calopa M, HernandezVara J, Tolosa E (2014) Nonmotor symptoms in LRRK2 G2019S associated Parkinson's disease. PLoS One 9:e108982. CrossRef Medline

Gerges NZ, Backos DS, Esteban JA (2004) Local control of AMPA receptor trafficking at the postsynaptic terminal by a small GTPase of the Rab family. J Biol Chem 279:43870-43878. CrossRef Medline

Giesert F, Hofmann A, Bürger A, Zerle J, Kloos K, Hafen U, Ernst L, Zhang J, Vogt-Weisenhorn DM, Wurst W (2013) Expression analysis of Lrrk1, Lrrk2 and Lrrk2 splice variants in mice. PLoS One 8:e63778. CrossRef Medline

Goffer Y, Xu D, Eberle SE, D’amour J, Lee M, Tukey D, Froemke RC, Ziff EB, Wang J (2013) Calcium-permeable AMPA receptors in the nucleus accumbens regulate depression-like behaviors in the chronic neuropathic pain state. J Neurosci 33:19034-19044. CrossRef Medline

Gofflot F, Chartoire N, Vasseur L, Heikkinen S, Dembele D, Le Merrer J, Auwerx J (2007) Systematic gene expression mapping clusters nuclear receptors according to their function in the brain. Cell 131:405-418. CrossRef Medline

Golden SA, Covington HE 3rd, Berton O, Russo SJ (2011) A standardized protocol for repeated social defeat stress in mice. Nat Protoc 6:1183-1191. CrossRef Medline

Greggio E, Bubacco L, Russo I (2017) Cross-talk between LRRK2 and PKA: implication for Parkinson's disease? Biochem Soc Trans 45:261-267. CrossRef Medline

Gustafsson H, Nordström A, Nordström P (2015) Depression and subsequent risk of Parkinson disease: a nationwide cohort study. Neurology 84:2422-2429. CrossRef Medline

Han MH, Nestler EJ (2017) Neural substrates of depression and resilience. Neurotherapeutics 14:677-686. CrossRef Medline

Hawkes CH (2008) The prodromal phase of sporadic Parkinson's disease: does it exist and if so how long is it? Mov Disord 23:1799-1807. CrossRef Medline

Hawkes CH, Del Tredici K, Braak H (2010) A timeline for Parkinson's disease. Parkinsonism Relat Disord 16:79-84. CrossRef Medline

Healy DG, Falchi M, O'Sullivan SS, Bonifati V, Durr A, Bressman S, Brice A, Aasly J, Zabetian CP, Goldwurm S, Ferreira JJ, Tolosa E, Kay DM, Klein C, Williams DR, Marras C, Lang AE, Wszolek ZK, Berciano J, Schapira AH, et al. (2008) Phenotype, genotype, and worldwide genetic penetrance of LRRK2-associated Parkinson's disease: a case-control study. Lancet Neurol 7:583-590. CrossRef Medline

Higashi S, Moore DJ, Colebrooke RE, Biskup S, Dawson VL, Arai H, Dawson
TM, Emson PC (2007) Expression and localization of Parkinson's disease-associated leucine-rich repeat kinase 2 in the mouse brain. J Neurochem 100:368-381. CrossRef Medline

Hodes GE, Pfau ML, Purushothaman I, Ahn HF, Golden SA, Christoffel DJ, Magida J, Brancato A, Takahashi A, Flanigan ME, Menard C, Aleyasin H, Koo JW, Lorsch ZS, Feng J, Heshmati M, Wang M, Turecki G, Neve R, Zhang B, et al. (2015) Sex differences in nucleus accumbens transcriptome profiles associated with susceptibility versus resilience to subchronic variable stress. J Neurosci 35:16362-16376. CrossRef Medline

Hume RI, Dingledine R, Heinemann SF (1991) Identification of a site in glutamate receptor subunits that controls calcium permeability. Science 253:1028-1031. CrossRef Medline

Isaac JT, Ashby MC, McBain CJ (2007) The role of the GluR2 subunit in AMPA receptor function and synaptic plasticity. Neuron 54:859-871. CrossRef Medline

Ishihara L, Brayne C (2006) A systematic review of depression and mental illness preceding Parkinson's disease. Acta Neurologica Scandinavica 113: 211-220. CrossRef Medline

Jaleel M, Nichols RJ, Deak M, Campbell DG, Gillardon F, Knebel A, Alessi DR (2007) LRRK2 phosphorylates moesin at threonine-558: characterization of how Parkinson's disease mutants affect kinase activity. Biochem J 405:307-317. CrossRef Medline

Jonas P, Racca C, Sakmann B, Seeburg PH, Monyer H (1994) Differences in $\mathrm{Ca}^{2+}$ permeability of AMPA-type glutamate receptor channels in neocortical neurons caused by differential GluR-B subunit expression. Neuron 12:1281-1289. CrossRef Medline

Kamboj SK, Swanson GT, Cull-Candy SG (1995) Intracellular spermine confers rectification on rat calcium-permeable AMPA and kainate receptors. J Physiol 486:297-303. CrossRef Medline

Kerestes R, Harrison BJ, Dandash O, Stephanou K, Whittle S, Pujol J, Davey CG (2015) Specific functional connectivity alterations of the dorsal striatum in young people with depression. Neuroimage Clin 7:266-272. CrossRef Medline

Khibnik LA, Beaumont M, Doyle M, Heshmati M, Slesinger PA, Nestler EJ, Russo SJ (2016) Stress and cocaine trigger divergent and cell typespecific regulation of synaptic transmission at single spines in nucleus accumbens. Biol Psychiatry 79:898-905. CrossRef Medline

Kreitzer AC, Malenka RC (2007) Endocannabinoid-mediated rescue of striatal LTD and motor deficits in Parkinson's disease models. Nature 445: 643-647. CrossRef Medline

Kreitzer AC, Malenka RC (2008) Striatal plasticity and basal ganglia circuit function. Neuron 60:543-554. CrossRef Medline

Krishnan V, Berton O, Nestler E (2008) The use of animal models in psychiatric research and treatment. Am J Psychiatry 165:1109. CrossRef Medline

Kudryavtseva NN, Bakshtanovskaya IV, Koryakina LA (1991) Social model of depression in mice of C57BL/6J strain. Pharmacol Biochem Behav 38:315-320. CrossRef Medline

Lee H, Melrose HL, Yue M, Pare JF, Farrer MJ, Smith Y (2010) Lrrk2 localization in the primate basal ganglia and thalamus: a light and electron microscopic analysis in monkeys. Exp Neurol 224:438-447. CrossRef Medline

Lerner TN, Kreitzer AC (2012) RGS4 is required for dopaminergic control of striatal LTD and susceptibility to parkinsonian motor deficits. Neuron 73:347-359. CrossRef Medline

Lim BK, Huang KW, Grueter BA, Rothwell PE, Malenka RC (2012) Anhedonia requires MC4R-mediated synaptic adaptations in nucleus accumbens. Nature 487:183-189. CrossRef Medline

Lim J, Bang Y, Choi JH, Han A, Kwon MS, Liu KH, Choi HJ (2018) LRRK2 G2019S induces anxiety/depression-like behavior before the onset of motor dysfunction with $5-\mathrm{HT}_{1 \mathrm{~A}}$ receptor upregulation in mice. J Neurosci 38:1611-1621. CrossRef Medline

Liu SQ, Cull-Candy SG (2000) Synaptic activity at calcium-permeable AMPA receptors induces a switch in receptor subtype. Nature 405:454458. CrossRef Medline

Longo F, Russo I, Shimshek DR, Greggio E, Morari M (2014) Genetic and pharmacological evidence that G2019S LRRK2 confers a hyperkinetic phenotype, resistant to motor decline associated with aging. Neurobiol Dis 71:62-73. CrossRef Medline

Lovinger DM (2010) Neurotransmitter roles in synaptic modulation, plasticity and learning in the dorsal striatum. Neuropharmacology 58:951961. CrossRef Medline 
Ma T, Cheng Y, Roltsch Hellard E, Wang X, Lu J, Gao X, Huang CCY, Wei XY, Ji JY, Wang J (2018) Bidirectional and long-lasting control of alcoholseeking behavior by corticostriatal LTP and LTD. Nat Neurosci 21:373383. CrossRef Medline

Ma YY, Lee BR, Wang X, Guo C, Liu L, Cui R, Lan Y, Balcita-Pedicino JJ, Wolf ME, Sesack SR, Shaham Y, Schlüter OM, Huang YH, Dong Y (2014) Bidirectional modulation of incubation of cocaine craving by silent synapse-based remodeling of prefrontal cortex to accumbens projections. Neuron 83:1453-1467. CrossRef Medline

Marcott PF, Gong S, Donthamsetti P, Grinnell SG, Nelson MN, Newman AH, Birnbaumer L, Martemyanov KA, Javitch JA, Ford CP (2018) Regional heterogeneity of D2-receptor signaling in the dorsal striatum and nucleus accumbens. Neuron 98:575-587.e4. CrossRef Medline

Mata IF, Wedemeyer WJ, Farrer MJ, Taylor JP, Gallo KA (2006) LRRK2 in Parkinson's disease: protein domains and functional insights. Trends Neurosci 29:286-293. CrossRef Medline

Matikainen-Ankney BA, Kezunovic N, Mesias RE, Tian Y, Williams FM, Huntley GW, Benson DL (2016) Altered development of synapse structure and function in striatum caused by Parkinson's disease-linked LRRK2-G2019S mutation. J Neurosci 36:7128-7141. CrossRef Medline

Menard C, Pfau ML, Hodes GE, Kana V, Wang VX, Bouchard S, Takahashi A, Flanigan ME, Aleyasin H, LeClair KB, Janssen WG, Labonté B, Parise EM, Lorsch ZS, Golden SA, Heshmati M, Tamminga C, Turecki G, Campbell M, Fayad ZA, et al. (2017) Social stress induces neurovascular pathology promoting depression. Nat Neurosci 20:1752-1760. CrossRef Medline

Nikitczuk JS, Patil SB, Matikainen-Ankney BA, Scarpa J, Shapiro ML, Benson DL, Huntley GW (2014) $N$-cadherin regulates molecular organization of excitatory and inhibitory synaptic circuits in adult hippocampus in vivo. Hippocampus 24:943-962. CrossRef Medline

Nishimune A, Isaac JT, Molnar E, Noel J, Nash SR, Tagaya M, Collingridge GL, Nakanishi S, Henley JM (1998) NSF binding to GluR2 regulates synaptic transmission. Neuron 21:87-97. CrossRef Medline

Paisán-Ruiz C, Lewis PA, Singleton AB (2013) LRRK2: cause, risk, and mechanism. J Parkinsons Dis 3:85-103. CrossRef Medline

Pan PY, Li X, Wang J, Powell J, Wang Q, Zhang Y, Chen Z, Wicinski B, Hof P, Ryan TA, Yue Z (2017) Parkinson's disease-associated LRRK2 hyperactive kinase mutant disrupts synaptic vesicle trafficking in ventral midbrain neurons. J Neurosci 37:11366-11376. CrossRef Medline

Parisiadou L, Yu J, Sgobio C, Xie C, Liu G, Sun L, Gu XL, Lin X, Crowley NA, Lovinger DM, Cai H (2014) LRRK2 regulates synaptogenesis and dopamine receptor activation through modulation of PKA activity. Nat Neurosci 17:367-376. CrossRef Medline

Pont-Sunyer C, Hotter A, Gaig C, Seppi K, Compta Y, Katzenschlager R, Mas N, Hofeneder D, Brücke T, Bayés A, Wenzel K, Infante J, Zach H, Pirker W, Posada IJ, Álvarez R, Ispierto L, De Fàbregues O, Callén A, Palasí A, et al. (2015) The onset of nonmotor symptoms in Parkinson's disease (the ONSET PD study). Mov Disord 30:229-237. CrossRef Medline

Ramonet D, Daher JP, Lin BM, Stafa K, Kim J, Banerjee R, Westerlund M, Pletnikova O, Glauser L, Yang L, Liu Y, Swing DA, Beal MF, Troncoso JC, McCaffery JM, Jenkins NA, Copeland NG, Galter D, Thomas B, Lee MK, et al. (2011) Dopaminergic neuronal loss, reduced neurite complexity and autophagic abnormalities in transgenic mice expressing G2019S mutant LRRK2. PLoS One 6:e18568. CrossRef Medline

Reimers JM, Milovanovic M, Wolf ME (2011) Quantitative analysis of AMPA receptor subunit composition in addiction-related brain regions. Brain Res 1367:223-233. CrossRef Medline

Russo SJ, Murrough JW, Han MH, Charney DS, Nestler EJ (2012) Neurobiology of resilience. Nat Neurosci 15:1475-1484. CrossRef Medline

Shen W, Flajolet M, Greengard P, Surmeier DJ (2008) Dichotomous dopaminergic control of striatal synaptic plasticity. Science 321:848-851. CrossRef Medline

Shen W, Plotkin JL, Francardo V, Ko WK, Xie Z, Li Q, Fieblinger T, Wess J, Neubig RR, Lindsley CW, Conn PJ, Greengard P, Bezard E, Cenci MA, Surmeier DJ (2015) M4 muscarinic receptor signaling ameliorates striatal plasticity deficits in models of L-DOPA-induced dyskinesia. Neuron 88:762-773. CrossRef Medline
Skibinski G, Nakamura K, Cookson MR, Finkbeiner S (2014) Mutant LRRK2 toxicity in neurons depends on LRRK2 levels and synuclein but not kinase activity or inclusion bodies. J Neurosci 34:418-433. CrossRef Medline

Smith AD, Castro SL, Zigmond MJ (2002) Stress-induced Parkinson's disease: a working hypothesis. Physiol Behav 77:527-531. CrossRef Medline

Steger M, Tonelli F, Ito G, Davies P, Trost M, Vetter M, Wachter S, Lorentzen E, Duddy G, Wilson S, Baptista MA, Fiske BK, Fell MJ, Morrow JA, Reith AD, Alessi DR, Mann M (2016) Phosphoproteomics reveals that Parkinson's disease kinase LRRK2 regulates a subset of Rab GTPases. eLife 5:e12813. CrossRef Medline

Taymans JM, Van den Haute C, Baekelandt V (2006) Distribution of PINK1 and LRRK2 in rat and mouse brain. J Neurochem 98:951-961. CrossRef Medline

Tepper JM, Sharpe NA, Koós TZ, Trent F (1998) Postnatal development of the rat neostriatum: electrophysiological, light- and electron-microscopic studies. Dev Neurosci 20:125-145. CrossRef Medline

Tritsch NX, Ding JB, Sabatini BL (2012) Dopaminergic neurons inhibit striatal output through non-canonical release of GABA. Nature 490:262-266. CrossRef Medline

Trusel M, Cavaccini A, Gritti M, Greco B, Saintot PP, Nazzaro C, Cerovic M, Morella I, Brambilla R, Tonini R (2015) Coordinated regulation of synaptic plasticity at striatopallidal and striatonigral neurons orchestrates motor control. Cell Rep 13:1353-1365. CrossRef Medline

Tsankova NM, Berton O, Renthal W, Kumar A, Neve RL, Nestler EJ (2006) Sustained hippocampal chromatin regulation in a mouse model of depression and antidepressant action. Nat Neurosci 9:519-525. CrossRef Medline

Verdoorn TA, Burnashev N, Monyer H, Seeburg PH, Sakmann B (1991) Structural determinants of ion flow through recombinant glutamate receptor channels. Science 252:1715-1718. CrossRef Medline

Vialou V, Robison AJ, Laplant QC, Covington HE 3rd, Dietz DM, Ohnishi YN, Mouzon E, Rush AJ 3rd, Watts EL, Wallace DL, Iñiguez SD, Ohnishi YH, Steiner MA, Warren BL, Krishnan V, Bolaños CA, Neve RL, Ghose S, Berton O, Tamminga CA, Nestler EJ (2010) DeltaFosB in brain reward circuits mediates resilience to stress and antidepressant responses. Nat Neurosci 13:745-752. CrossRef Medline

Volta M, Cataldi S, Beccano-Kelly D, Munsie L, Tatarnikov I, Chou P, Bergeron S, Mitchell E, Lim R, Khinda J, Lloret A, Bennett CF, Paradiso C, Morari M, Farrer MJ, Milnerwood AJ (2015) Chronic and acute LRRK2 silencing has no long-term behavioral effects, whereas wild-type and mutant LRRK2 overexpression induce motor and cognitive deficits and altered regulation of dopamine release. Parkinsonism Relat Disord 21: 1156-1163. CrossRef Medline

Volta M, Beccano-Kelly DA, Paschall SA, Cataldi S, MacIsaac SE, Kuhlmann N, Kadgien CA, Tatarnikov I, Fox J, Khinda J, Mitchell E, Bergeron S, Melrose H, Farrer MJ, Milnerwood AJ (2017) Initial elevations in glutamate and dopamine neurotransmission decline with age, as does exploratory behavior, in LRRK2 G2019S knock-in mice. eLife 6:e28377. CrossRef Medline

West AB, Moore DJ, Biskup S, Bugayenko A, Smith WW, Ross CA, Dawson VL, Dawson TM (2005) Parkinson's disease-associated mutations in leucine-rich repeat kinase 2 augment kinase activity. Proc Natl Acad Sci U S A 102:16842-16847. CrossRef Medline

Xiong Y, Neifert S, Karuppagounder SS, Liu Q, Stankowski JN, Lee BD, Ko HS, Lee Y, Grima JC, Mao X, Jiang H, Kang SU, Swing DA, Iacovitti L, Tessarollo L, Dawson TM, Dawson VL (2018) Robust kinase- and agedependent dopaminergic and norepinephrine neurodegeneration in LRRK2 G2019S transgenic mice. Proc Natl Acad Sci U S A 115:16351640. CrossRef Medline

Yue M, Hinkle KM, Davies P, Trushina E, Fiesel FC, Christenson TA, Schroeder AS, Zhang L, Bowles E, Behrouz B, Lincoln SJ, Beevers JE, Milnerwood AJ, Kurti A, McLean PJ, Fryer JD, Springer W, Dickson DW, Farrer MJ, Melrose HL (2015) Progressive dopaminergic alterations and mitochondrial abnormalities in LRRK2 G2019S knock-in mice. Neurobiol Dis 78:172-195. CrossRef Medline 